\title{
Land-Use and Land-Cover Change in the Sahel Area of Keita Valley, Republic of Niger
}

\author{
Boureima Karidjo Yacouba', Zhanqi Wang1, Yamba Boubacar ${ }^{2}$ \\ ${ }^{1}$ Department of Land Resources Management, School of Public Administration, China University of Geosciences, \\ Wuhan, China \\ ${ }^{2}$ Geography Department, Faculty of Arts and Human Sciences, Abdou Moumouni University of Niamey, Niamey, \\ Niger \\ Email: byk2000@yahoo.fr, zhqwan@cug.edu.cn,byamba@refer.ne
}

Received 23 February 2016; accepted 25 March 2016; published 30 March 2016

Copyright (C) 2016 by authors and Scientific Research Publishing Inc.

This work is licensed under the Creative Commons Attribution International License (CC BY).

http://creativecommons.org/licenses/by/4.0/

c) (i) Open Access

\begin{abstract}
Keita region is largely dependent on agriculture and livestock as the main economic activities with about $90 \%$ of the population are actively engaged in rural activities. However, these activities are dwindling at a rate that corresponds with increase in the ecosystem's vulnerability. The following study focused on land use/land cover change in Keita. The study aims to better understand changes through diachronic analysis by integrating remote sensing and GIS. There was an interpretation of satellites imagery $(1975,1984,1995$ and 2001), and statistical techniques were used to provide quantitative analysis of land use/cover change information and drivers underlying in the study area. The changes are affected by simultaneous influence of successive droughts (1973-1974 and 1983-1984) that have transformed ecological balance, anthropogenic and livestock impacts, ecosystems degradation and policies. The land use temporal dynamics are undergone continual degradation of vegetation, the state of land saturation results in conflicts between farmer and herders, the drop in grazing areas, bare land expansion, the erosion of stream bed, and the decline in flooded plain.
\end{abstract}

\section{Keywords}

Keita Valley, Ecosystem's Vulnerability, Diachronic Analysis, Ecological Balance, Droughts

\section{Introduction}

The World Forest Congress on "Global Forest Resources Assessment 2015" notes that the world's forests continue to shrink as populations increase and woodlands are converted to agriculture and other uses, however, over the past 25 years, the rate of net global deforestation has slowed down by more than 50\%. Africa and South 
America had the highest net annual loss of forests in 2010-2015, with 2.8 and 2 million hectares respectively, but it notes how the rate of loss has "substantially decreased" from the previous five years period [1] (FAO, 2015), still tropical forests loss is more higher than that in boreal zones. Speedy population growth impacts the demand of farmland for human and animal feeding. It induces an extension of cropland and threat on biodiversity. Plant cover degradation leads to soil erosion, reduces crops, frees the carbon in degraded areas, and then accelerates global warming. In Africa, the land question has its origins in geo-political, economic, social and demographic factors more recently compounded by emerging global and strategic imperatives. These include different forms and modes of colonization experienced in various regions, the diversity and degree of persistence of indigenous cultural and normative systems and forms of economic organizations [2] (Land Policy in Africa, 2010). Land-use shifts caused by external and internal drivers have influenced many traditional resource management regimes in arid and semi-arid areas (Campbell et al., 2005; Reid et al., 2004) quoted by [3] (Tsegaye et al., 2010). Sahel is the world's largest semi-arid rangeland; it stretches from Senegal in the West Africa to Somalia in the east, and harbours a population of around 70 million people [4] (FAO, 2001). The population increased from 17 million in 1950 to 81 million in 2012, representing a fivefold increase in 60 years. Average projections show 117 million expected in 2025 and 208 million in 2050 [5] (Ouallet, 2013). Well before the global environmental community became obsessed with global warming or ozone depletion, the Sahel region of West Africa had come to represent what was called the quintessence of a major environmental emergency, (Claude Raynaut) quoted by [6] (Batterbury \& Warren, 2001). In the later twentieth century, the majority of global land cover changes have occurred in the tropical regions, and the Sudano-Sahelian zone is among these [7] (Reenberg, 2001). Sahel environment was marked by milestones of climate impacts (1970s-1980s droughts) and degradation periods with an expansion to a general degradation. According to Batterbury and Warren (2001) there has been a $20 \%-30 \%$ net decline in Sahelian rainfall in the latter part of the $20^{\text {th }}$ century, and the 1970 s droughts were indeed almost unique in their severity. The change of land use pattern is an important cause of the environmental degradation observed in the Sahel; many experts believed that stretching agriculture land led to a vicious circle, which had often increased economic poverty. Some studies of land-use/cover changes at regional or local levels often dealt exclusively with quantifying land-use/cover changes using remote sensing tools or focused on causes of land-use/cover changes through socio-economic surveys.

The overall perception is that the environment in Niger (Sahel) continues to deteriorate, that food security is not improved, rural poverty increases, there is no agricultural intensification and that the efforts made by the various actors in the fight against environmental degradation and improving the living conditions of the population have been limited. This study focuses on the analysis of land use and changes that occur between 1975, 1984, 1995 and 2007 in Keita valley, several papers were produced about Keita, some pointed the climate factors (rains, droughts, temperatures, desertification...) and other emphasized their research on human caused degradation (demographic pressure, agriculture, breeding). However, in this paper, by addressing the subject, we combine various aspects of Keita, not only climate or human causes in land use and changes that happened. This study aims to detect the long term land use/cover shifts, to determine the main drivers of the shifts. Geographical information system (GIS) was used in order to provide analysis of land use/cover change information in Keita area. This study will be of immense importance in this area where many actors were involved in development projects. Land use/cover changes study provides statistics that help to understand the link between human activities, their environment and the interactions. Moreover, it will give a great insight about the study area.

\section{Keita Valley}

Located in Tahoua (regional capital), about $72 \mathrm{~km}$ between $14^{\circ} 20^{\prime} \mathrm{N}$ and $15^{\circ} 10^{\prime} \mathrm{N}$ latitude and $5^{\circ} 20^{\prime} \mathrm{E}$ and $6^{\circ} 95^{\prime} \mathrm{E}$ longitude. It covers an area of $4860 \mathrm{~km}^{2}$; characterized by trays with rocky slopes and valleys forming a complex system of watersheds exposed to strong winds and water erosion. Keita is part of the ADM (Ader-DoutchiMaggia), a very hilly area with rocky hills and plateaus, foothills border glazes crossed by few seasonal valleys (koris). Keita's position at the northern edge of cultures, which is officially isohyet $250 \mathrm{~mm}$, overlaps the breeding area often causing conflicts between pastoralists seeking more space to crop and transhumant herders.

Keita area is located in northern of the Sahel climate zone, characterized by a short rainy season June to September, the Monsoon wind from south prevails; and a long dry season from October to May dominated by Harmattan wind blowing from Sahara. Here, the climate characteristics meet the criterion of water availability, or more exactly to the amount and distribution of rainfall during the year. Temperatures are generally between 
$17^{\circ} \mathrm{C}$ and $40^{\circ} \mathrm{C}$, maximum heat in May-June and lowest in January. The average relative humidity is $44 \%$ but is subject to strong variations, $21 \%$ in February to 74\% during the month of August [8] (PAFAGE, 2005). The average annual rainfall is between 300 and $400 \mathrm{~mm}$ with oscillations that reach $200 \mathrm{~mm}$ from south to North. The region has undergone a steady decline in rainfall during the period 1960-1990, particularly reduction in August rainfall.

\section{Methods and Materials}

In this study, time series of LULC data sets were used (1975-1984-1995-2007), data processing and classification were performed using Microsoft Excel, Arc Map 10.2 softwares and statistical methods using cross-tabulation; SPSS to evaluate diachronic changes were performed.

1975 digitized topographic maps on scale of 1:50,000; Landsat TM-4 Coverage of 1984 (2 frames of 15/10/ 1984 and 09/11/1984) with $30 \mathrm{~m}$ of spatial resolution using false colors in the composite 432; SPOT HRV-3 (05/09/1995) with $20 \mathrm{~m}$ of spatial resolution using false colors composite 321; Terra ASTER (2 frames of 20/01/2007 and 19/12/2007) spatial resolution of 15 m using false colors composite 321 .

These dates were selected on the basis of the availability of satellite images. All images were geo-referenced using topographic map as a master image. The Universal Transverse Mercator (UTM) geographic projection, (Niger) zone 30 North datum were used in geo-referencing the images. Three fundamental colors have been attributed to the image bands, near infrared band was coded red color, red band was coded green color and green band was coded blue color. Computer observation of color composite showed the presence of vegetation in deep red, crops in light read, bare land plateau in blue, water in light blue, bare rock in green. All images were re-sampled to a lower resolution $(15 \mathrm{~m})$ in order to improve and optimize treatment output, make clear all land use/cover units in the study area and identify them perfectly.

Digitizing of thematic units, descriptive attributes capture were carried out. Many field trip checking information of the pixel matrices outlines for each type of land use/cover were identified and computed; in total 3843 polygons were digitized in the four periods under observation. However, each period polygons differ according to the changes occurred, then in 1975; 1984; 1995; 2007 respectively 373 polygons; 845 polygons; 961 polygons and 1664 polygons. Extracted data were hosted in layers created (water flow, roads, and land use/cover units...). After digitizing and filing layers, the attributes capture was made. Then, layers of land use/cover have been defined by creating a table containing the different units of land use/cover and digital key code for linking each polygon, line and point to all of its attributes. Furthermore, a cross-tabulation detection method was employed to perform change detection of LULC using diachronic tool: F-I/I*100 (I = Initial year area; F = Final year area) in percentage, see (Tsegaye et al., 2010).

The land use change showed quantitative data of the overall LUCC changes between 1975 and 2007 in the study area. To detect the variability of change per land unit during 1975-2007, analysis of variance (ANOVA) (Table 1) was employed to quantitatively examine the relationship between LULC changes, and provide further information for this study. After carefully checking the significance levels for the overall distribution and interaction effects of the variables, however, the lack of time series data did not give enough variables for expected analysis.

\section{Results}

To meet Niger land use/cover nomenclature composed of (thirteen land use/cover units), some land units were merged to form one, such as crops under wooded park and rainfed crop; bare rock and lateritic areas which is nude too; off-season cash crops and irrigated crop. The years under review showed a maximum of twelve land units and a minimum of ten depending on the changes that occurred, events such as droughts of 1973 and 1984 mainly influenced those changes.

As can be observed from summary of (Table 2), the land use/cover change of Keita area since 1975 was considerable. Between 1975 and 2007, the tree steppe area increased moderately from 2.04\% to 2.59\% and by 1984, it had fallen to $0.71 \%$, and then increased to 6.48 in 1995 Table 2.

The decrease in shrub steppe and grassy steppe cover was large during the time-period under review: 1975, 1984, 1995 and 2007; both the units saw similar declines but more pronounced in grassy steppe with 14.8\%, 14.71\%, 3.47\%, 0.29\% and 35.37\%, 18.41\%, 12.44\%, 3.82\% for the shrub steppe (Table 2). The rainfed crop proportion increased exponentially from 1.97\%, 22.83\%, 39.12\%, and 60.42\% respectively in 1975, 1984, 1995 
Table 1. ANNOVA one way: Cover change between periods.

\begin{tabular}{cccccc}
\hline & Sum of Squares & df & Mean Square & F & Sig. \\
\hline Between Groups & $4,8337,899.139$ & 11 & $4,394,354.467$ & 3.806 & 0.000 \\
Within Groups & $6,9276,225.482$ & 60 & & & \\
Total & $1.176 \mathrm{E} 8$ & 71 & $1,154,603.758$ & & \\
\hline
\end{tabular}

Table 2. Land use/cover states in percentage from 1975, 1984, 1995 and 2007 in Keita Valley.

\begin{tabular}{|c|c|c|c|c|c|c|c|c|}
\hline \multirow{3}{*}{ LUCC units } & \multicolumn{8}{|c|}{ Years } \\
\hline & \multicolumn{2}{|c|}{1975} & \multicolumn{2}{|c|}{1984} & \multicolumn{2}{|c|}{1995} & \multicolumn{2}{|c|}{2007} \\
\hline & На & $\%$ & На & $\%$ & На & $\%$ & На & $\%$ \\
\hline Tree steppe & 9641.32 & 2 & 3363.24 & 1 & $30,662.74$ & 6 & $12,240.17$ & 3 \\
\hline Shrub steppe & $167,450.33$ & 35 & 87,159.22 & 18 & $58,906.58$ & 12 & $18,103.22$ & 4 \\
\hline Grassy steppe & $70,037.36$ & 15 & 69,632.06 & 15 & $16,438.63$ & 3 & 1368 & 0 \\
\hline Rainfed crop & 9315.34 & 2 & $108,078.67$ & 23 & $185,198.58$ & 39 & $285,999.45$ & 59 \\
\hline Bare rock & $148,281.31$ & 31 & $147,993.01$ & 31 & $143,355.22$ & 30 & $139,872.05$ & 30 \\
\hline $\begin{array}{l}\text { Intermittent } \\
\text { flow kori) }\end{array}$ & 3530.93 & 1 & 5922.42 & 1 & 4560.76 & 2 & 4662.31 & 1 \\
\hline Sand soil & $47,289.6$ & 10 & 3242.64 & 1 & $23,664.75$ & 5 & 245.33 & 0 \\
\hline Riparian area & $13,714.97$ & 3 & $47,001.31$ & 10 & 7355.42 & 2 & 3920.42 & 1 \\
\hline Irrigated crop & 4071.74 & 1 & 927.57 & 0 & 2417.17 & 1 & 3381.53 & 1 \\
\hline Fallow & 0 & - & 0 & 0 & 400.36 & 0 & 148.23 & 0 \\
\hline Pond & 0 & - & 0 & 0 & 306.02 & 0 & 512.8 & 0 \\
\hline Villages & 35.1 & - & 47.88 & 0 & 101.8 & 0 & 2914.51 & 1 \\
\hline Total & 473,368 & $100 \%$ & 473,368 & $100 \%$ & 473,368 & $100 \%$ & 473,368 & $100 \%$ \\
\hline
\end{tabular}

and 2007; induced by the extension of cropland. The bare rock and intermittent flow decreased moderately, showing a little change during the 32-year period. The riparian area trebled during the earlier time period 19751984 compared to the recent time period 1995-2007, whereas the sand soil and irrigated crop units declined during the period 1975-1984, their proportions increased during the period 1995-2007. The fallow and ponds units appeared during the recent time period of 1995-2007, the first one cover declined by 2007 while ponds gently increased.

The human settlement; during the earlier time period of 1975-2007 no change occurred, and then extremely increased by 1995-2007 time period (Table 3 and Figure 1). To determine how significant the changes are within land units; Table 1 shows the general pattern of the changes in land units during all the periods. Based on the results of the one way ANOVA the land units' changes differ significantly across different periods (since $\mathrm{F}_{11,71}$ $=3.806, \mathrm{P}=0.000<0.05$ ) (Table 1 ). Furthermore, to see which land unit's change varied significantly from another, Tukey multiple mean comparison method was employed and reveals that change in villages is significantly different from change in all the other land units except rainfed crop as their P-values $(0.003,0.001,0.001$, $0.001,0.001,0.001,0.001,0.001,0.001,0.001$ respectively) are less than 0.05 .

\section{Drivers of Land Use Cover Change}

Driving forces are of different sources: climate, cultural and political issues. Keita valley as other zones of Niger country has been facing a persistent lack of rainfall, combined with anthropogenic factors such as monoculture agriculture, failure or lack of fertilization, grazing, among others. The main identified drivers for land cover change in the zone include anthropic and climate factors.

Climate factors are mainly pointed by successive droughts (1973-1974 and 1983-1984) that affected the country, with lower rainfall and irregularity in time and space. Indeed, the cumulative effects of drought and 
Table 3. Keita’s land use/cover change cross-tabulation (1975-2007).

\begin{tabular}{|c|c|c|c|c|c|c|c|c|c|c|}
\hline \multirow{2}{*}{ LUCC units } & \multicolumn{4}{|c|}{ Absolute area cover/year in Ha } & \multicolumn{6}{|c|}{ Cover change between periods in \% } \\
\hline & 1975 & 1984 & 1995 & 2007 & 1975-1984 & $1975-1995$ & $1975-2007$ & 1984-2007 & 1984-1995 & $1995-2007$ \\
\hline Tree steppe & 9641.32 & 3363.24 & $30,662.74$ & $12,240.17$ & -65.12 & 218.03 & 26.96 & 263.94 & 811.7 & -60.08 \\
\hline Shrub steppe & $167,450.33$ & $87,159.22$ & $58,906.58$ & $18,103.22$ & -47.95 & -64.82 & -89.19 & -79.23 & -32.41 & -69.27 \\
\hline Grassy steppe & $70,037.36$ & $69,632.06$ & $16,438.63$ & 1368 & -0.58 & -76.53 & -98.05 & -98.04 & -76.39 & -91.68 \\
\hline Rainfed crop & 9315.34 & $108,078.67$ & $185,198.58$ & $285,999.45$ & 1060.22 & 1888.1 & 2970.2 & 164.62 & 71.36 & 54.43 \\
\hline Bare rock & $148,281.31$ & $147,993.01$ & $143,355.22$ & $139,872.05$ & -0.19 & -3.32 & -5.67 & -5.49 & -3.13 & -2.43 \\
\hline $\begin{array}{l}\text { Intermittent } \\
\text { flow kori) }\end{array}$ & 3530.93 & 5922.42 & 4560.76 & 4662.31 & 67.73 & 29.17 & 32.04 & -21.28 & -22.99 & 2.23 \\
\hline Sand soil & $47,289.6$ & 3242.64 & $23,664.75$ & 245.33 & -93.14 & -49.96 & -99.48 & -92.43 & 629.8 & -98.96 \\
\hline Riparian area & $13,714.97$ & $47,001.31$ & 7355.42 & 3920.42 & 242.7 & -46.37 & -71.42 & -91.66 & -84.35 & -46.7 \\
\hline Irrigated crop & 4071.74 & 927.57 & 2417.17 & 3381.53 & -77.22 & -40.64 & -16.95 & 264.56 & 160.59 & 39.9 \\
\hline Fallow & 0 & 0 & 400.36 & 148.23 & 0 & 0 & 0 & 0 & 0 & -62.98 \\
\hline Pond & 0 & 0 & 306.02 & 512.8 & 0 & 0 & 0 & 0 & 0 & 67.57 \\
\hline Villages & 35.1 & 47.88 & 101.8 & 2914.51 & 36.41 & 190.03 & 8203.45 & 5987.11 & 112.61 & 2762.98 \\
\hline Total & 473,368 & 473,368 & 473,368 & 473,368 & & & & & & \\
\hline
\end{tabular}

F-I/I*100 (I = Initial year area; F = Final year area); see (Diress, 2010).

\section{Cover change between periods}

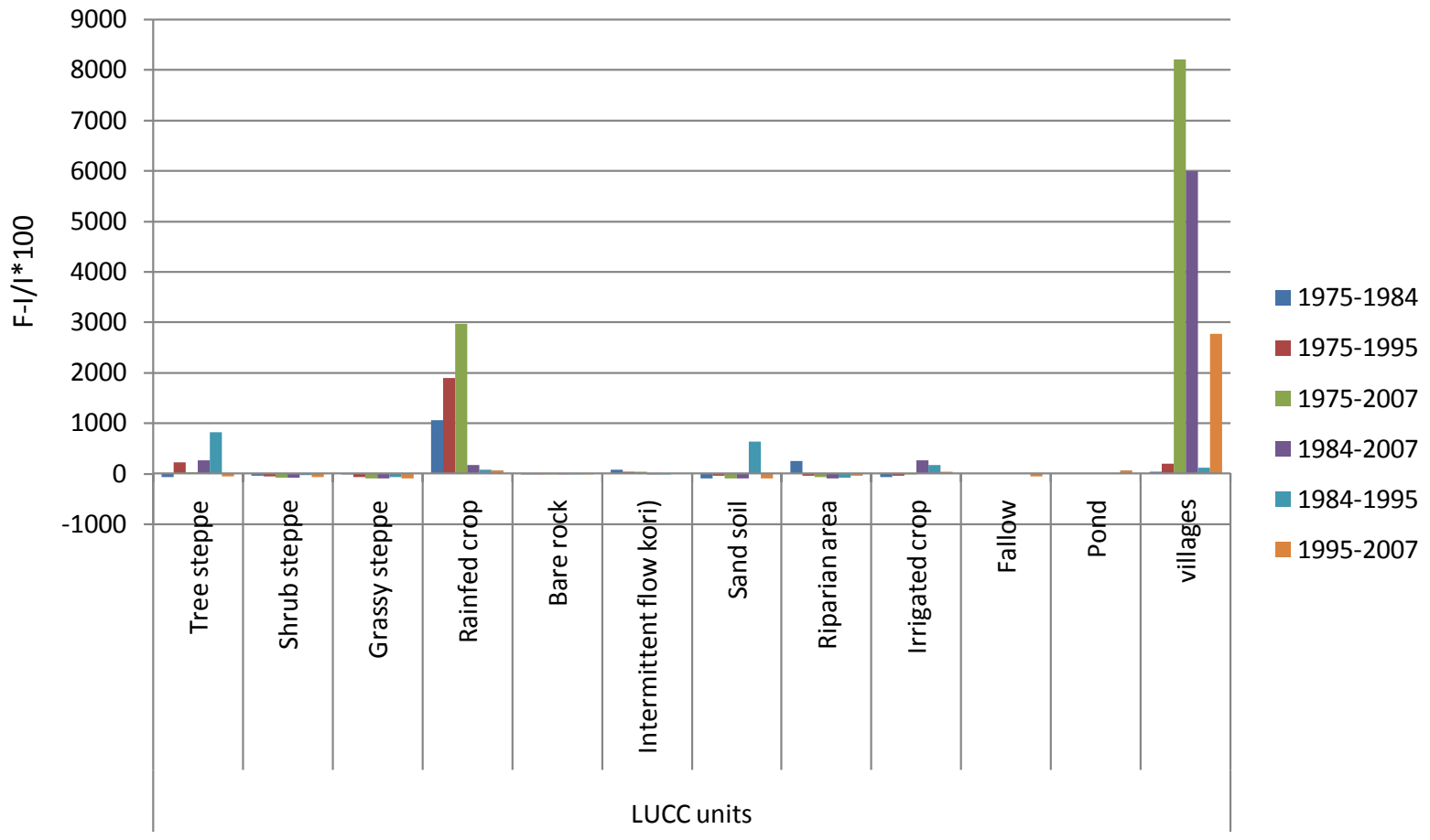

Figure 1. Land cover between periods.

irregular pattern of rainfall have lead to a degradation of the ecosystem and shift in vegetation cover also the fall in the crop yield. This shift leads to the clearing of land for crop development. Persistent droughts have destroyed much of the resources thereby contributing to the settling of the herders, prompting the emergence of 
new needs for cropland. Wind erosion in the area has an influence on its land use/cover change. There are two types of winds; the monsoon blowing southwest during the rainy season and Harmattan northeast during the dry season. The Harmattan action is very effective, with an average speed of $6-7 \mathrm{~m} / \mathrm{s}$ to $1.8 \mathrm{~m}$ above the floor and 9 $10 / \mathrm{s}$ to $10 \mathrm{~m}$ high, causing damage to crops and eroded areas less protected. The wind erosion is significant as it accelerated the silting-up of farmland and consequently reduced their areas. Wind also contributed to the loss of the thin topsoil that covered the surface of the cuirassed soil which was a result of overgrazing, thus accelerating the spread of dunes and puts additional pressure on the remaining natural vegetation. One consequence of the reduction in vegetation cover is that it affects the flow speed in the kori, particularly Tamaské Basin, the main kori flows for many km between two high walls of three to five meters, with a bed width of koris which varies from 30 to 50 meters; it is increasing year by year during the rainy season. Occasionally there is minor side slits arriving in the main koris. The bottom of these water collectors is rather sandy, often rocky [9] (PEICRE, 1998). The more one moves upstream the kori, more obvious and serious is the process of hydric erosion. They can no longer recharge the water table, so the infiltration of runoff water is weakened, resulting in the decreased production of sorghum and millet, destruction of cultivated land, and every year granaries are empty, despite the land degradation caused by the koris, peasants continue farming the edges of water flow because of the lack of farmland.

Keita suffered from the 1970s and1980s droughts leading to rural exodus, more than $20 \%$ of the population moved to cities or bordering countries, half of the livestock had been decimated [10] (Tarchiani \& Roua, 2010). According to the census of 2012, Keita's population was 15,975 in 1988; 218,337 in 2001 and 337,635 inhabitants with $2.4 \%$ of growth rate [11] (RGP/H, 2012), rising the pressure on existing resources. High population growth had played a role on the land use pattern by influencing its changes. In addition, the increase in population results in the emergence of new needs, part of which is food production. This situation further emphasized the pressure on land resources with a consequent reduction in fallow periods from 5 years to the complete absence of fallow. Due to the poverty of the renewable resources, yields have declined, and to counteract this, marginal land and grazing areas have been brought into cultivation and the fallow period has been shortened or is no longer existent [12] (Reenberg \& Paarup-Laursen, 1997). The dangers of production loss are becoming real in this part of Africa [13] (Larwanou \& Saadou, 2010).

Population growth rate is proportional to a demand for agricultural products, thus a consequent need for farmland. Expansion of cropland and pastoral land is driven by changes in human and animal populations, which increase the consumption demand for food crops and forage, and interannual variability in rainfall, which modifies land productivity and therefore increases or decreases production for a given area under a pastoral or cultivation use. The population growth and its Changes in age structure (with more youths than ever) are some reasons of cropland extension at the expense of grazing areas, causing deforestation and expansion of bare land. The migration from Keita to south or neighbouring countries also had influence on the land use/cover change specially during the drought periods.

Land use/cover changes are also influenced by certain decisions made by government and even traditional authority. At the national level, a number of policies have been adopted and implemented in order to ensure environmental protection and the sustainable management of natural resources but the policies failed to address the real problems faced in rural area; i.e. the 61-05 law of 26 May 1961 and the 61-06 law of 27 May 1961 that set the north boundary of cultures and erect the area as pastoral modernization zone. These two laws have not been repealed by the Rural Code but are not respected in practice; because the rural population of Keita continues clearing in pastoral area to solve their demand of farmland.

\section{Discussion}

The Keita valley experienced substantial rates of land-use/cover changes during 32 years from 1975 to 2007. There have been persistent changes, both spatially and temporally, among the land cover types. The state of vegetation cover observed during this period indicates that most of the vegetation types suffered from direct and indirect drought effects. The most affected land unit was grassy steppe from 70,037.36 Ha in 1975 decreased to $1368 \mathrm{Ha}$ in 2007, particularly in the plateau areas. This area became farmland in consequence of several droughts that impoverished cultivated land. The fact is that, Keita "which is nine years deficit over ten for thirty years" (PEICRE, 1998). On another note, the yearly average rainfall from 1956 to 1965 is $528 \mathrm{~mm}$ per year. This average drops to $417 \mathrm{~mm}$ per year in the following decade, from 1966 to 1975. In the period from 1976 to 
1984 the yearly average dropped once again to $364 \mathrm{~mm}$ per year [14] (Haji, 1994). The decreasing in grassy vegetation and forest cover in the region is undoubtedly an important factor in shifting to cropland.

Many studies on drylands documented a decline in woody vegetation cover; however, in the study area, the woodland showed sawtooth trend during the period under observation (1975-2007). Rather, observations revealed modification of woodland cover induced by the PIK (Integrated Project of Keita implemented in 1984). Positive trends in NDVI residuals are observed in the Tahoua and Maradi regions, centering around the area of Keita, an extensive rural development program with a focus on natural resource management and soil and water conservation which began in the early 1980s supported by the Food and Agriculture Organization [15] (Herman, 2005). F.A.O (Food and Agriculture Organization), the Italian government and the Nigerien government signed an agreement to implement the "Projet de Développement Rural Intégré de Keita (P.I.K. or project Keita) in 1984. The objectives of Keita project were, to reclaim abandoned land and protect land that was already being cultivated in order to improve agriculture, livestock activities and environment management for better living conditions in Keita. Thanks to Keita project, during its implementation large uncultivated areas have been reclaimed for agriculture and breeding activities (27000 Ha, 20000000 trees were planted).

In 1962, there were areas of forest on the slopes; the ponds of Keita were covered with classified forests. Also, on the 1958 map, dune areas were not extensive. The surfaces of the glaze and lower slopes are covered with sand carried by the wind. Thus form glazes and silted slope. These dune lands on stabilized Aeolian deposits are relatively rich in natural vegetation, trees and shrubs, and many are exploited for millet and for grazing after culture. However, they have the disadvantage of being vulnerable to wind erosion, especially after long periods of drought when the surface of the ground is dry. These deposits are mobile, sand dunes, and so extensive that they constitute a real threat to villages and nearby fields. By the year 1984 an agony of plant cover was reported, which began in 1972. A survey to the village chief of Keita proved it: "All the trees are dead. The shortage of firewood was obvious; when the millet stalks reserve is over, households bought wood" this shortage is due to the cutting of trees by the population, but also the disastrous floods that uproot trees and shrubs by its waves. However, the change that occurred in 1995 and 2007 hides the fact that a large part of these units carries some trees or shrubs vegetation, they become either a rainfed crop under shrub park or under wooded park or irrigated crop; forestry and pastoral lands recovered are also invaded by rain-fed agriculture.

Keita region is characterized by a wide slits and rocky relief that form slopes with extensive valley floors, interconnected by flat surfaces, glazes. The study area has always been a transit area of the nomadic pastoral system of the North and the agricultural South of Niger. Before the droughts of the 1970s and 1980s, agriculture and livestock lived together but were practiced by different groups. A study conducted in 1985 show that farmers had little interest in the breeding, which was Pular and Tuareg activity. However, today, the distinction between farmers and breeders from the viewpoint of animal husbandry practices or agriculture is very low, and yet conflicts between sedentary agro-pastoralists and pastoralists persist. Rangelands in arid or semi-arid tropical and subtropical zones are increasingly seen as non-equilibrium ecosystems. Modification in the biological productivity of these rangelands at the annual to decadal time scales is mainly governed by biophysical drivers (e.g., interannual rainfall variability, ENSO events), with stocking rates having less long-term effect on productive potential (Behnke et al., 1993) quoted by [16] (Lambin et al., 2001). The corridors and grazing areas are often cultivated and livestock must move on roads or their edges. Indeed, the department is crossed by corridors for thransumant herders, in the southern border by an international corridor as well as by regional corridors. In pastoral areas, fields already extend the north of cropland, which is officially isohyet $250 \mathrm{~mm}$. In addition to the conflicts linked to competition for access to land, management of water sources and land control on pastures are set separately by the legislation. The historical relations between pastoral and agricultural societies (manure contracts, agreement on grazing, product exchanges) are marked by competition for land and natural resources, which is reflected particularly by the progressive occupation of transhumance corridors and therefore conflicts have become increasingly rampant.

Some development actors (e.g., PIK), improve the practice of sustainable agriculture system and assisted the peasants in their flood diversion activities have in fact contributed to reclaim uncultivable lands, equipped villages with infrastructures (roads, market...), however, the practice of shifting cultivation that converts more vegetated areas to cropping fields increased. By the year 1964, the demographic and economic thrusts lead to the disappearance of nomadism and fallow for lack of arable land; and each year, the majority of alluvial clay and glaze of calcareous origin, for an uncultivated period bear cotton and sorghum crops. A large part of the field is used to grow millet and sorghum. Only $28 \%$ of the land is arable, the overall territory is composed of rocky 
slopes. The soils are shallow with fine texture silty clay, classified in the sub-class of steppe soils with saturated complex; their characteristics are hot and humid during the short rains [17] (Roselt, 2006). A survey conducted in 1985 on the use of organic fertilizer by farmers note that, (30\% of respondents use it in a massive and continuous way, while $38 \%$ sporadically practiced manure). However, there are many areas where this practice was abandoned after the project (P.I.K) implementation. Cultivation practices adopted by farmers in Keita are subject to the rules of the "monophytic linear succession" that cause soil depletion, since it is always the same plant species that succeeded in time. This practice involves the need to abandon fallow land and is therefore strictly related to shifting cultivation.

The way a community manages her space and resources is strongly influenced by cultural values and this is can also affect the land use dynamics. The competition between farmers to acquire the coveted honorary title of "Sarkin Noma" (farmer who records the highest agricultural production rate in the area) has led many farmers to cultivate more and hence massive land clearing for agricultural use. The Islamic theory that encourages procreation in order to expand the Muslim community has also aided population growth which provoked a negative trend in land use/cover patterns. Fallow was also negated as a result of inheritance which rendered some hitherto, family farmlands to individually owned ones [18] (Issiaka et al., 2012).

Immigration has been present since 1962, but has undergone changes; the net increase until 1985 is followed by a gradual decrease. This is explained both by alteration of the environmental balance (area of cultivated fields, soil fertility, population distribution) than the social (social cohesion, settling nomadic population) (Figures 2-5). Cities attract a significant proportion of the rural population by way of permanent and circulatory migration, and the wages earned in the city are often remitted by migrants to rural homelands, in some cases transforming the use of croplands and creating "remittance landscapes" (Lambin et al., 2001). Male exodus is even more

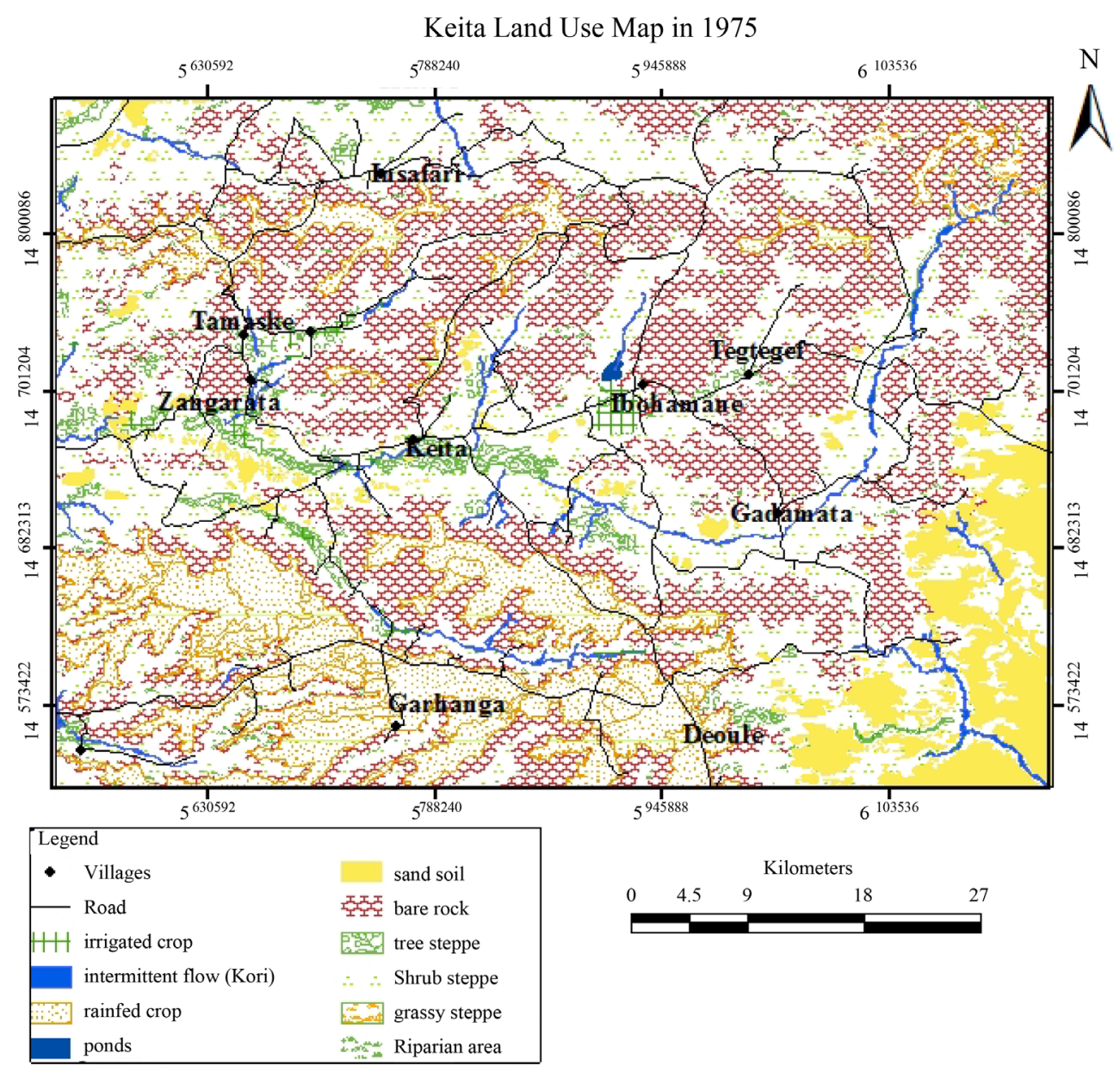

Figure 2. Keita land use map in 1975. 


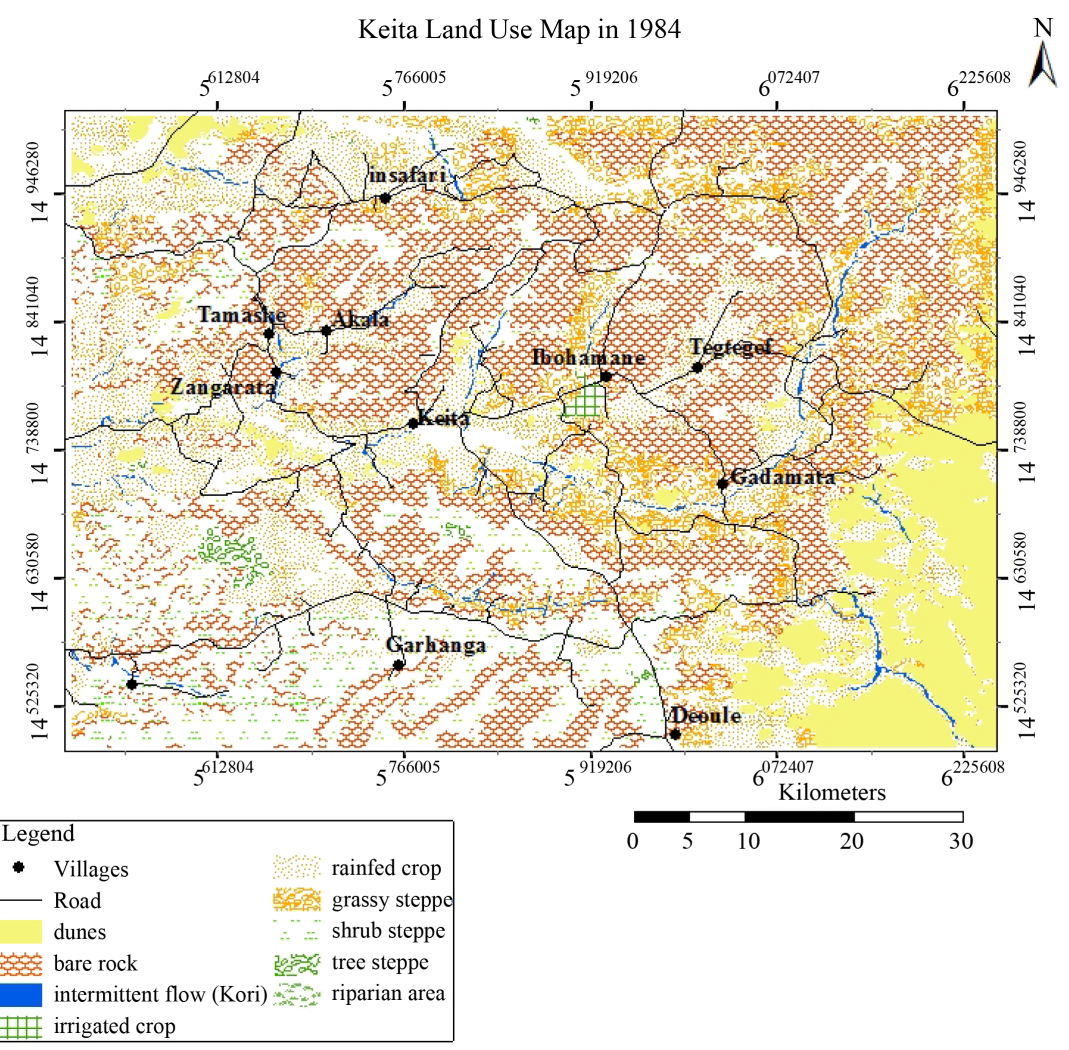

Figure 3. Keita land use map in 1984.

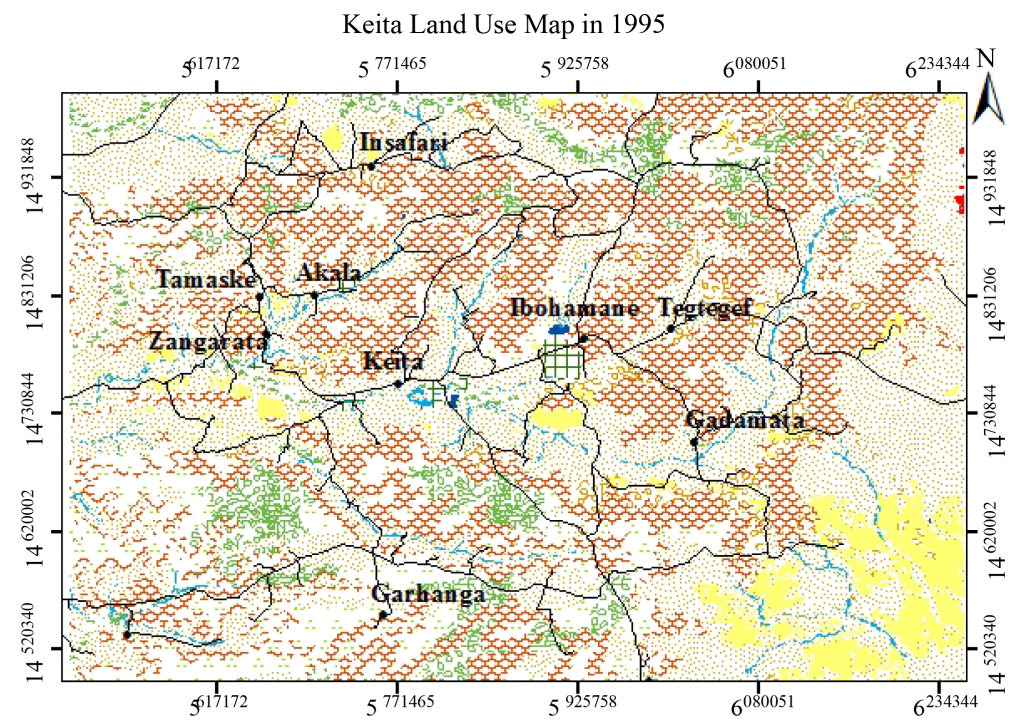

\begin{tabular}{|c|c|c|}
\hline \\
\hline \multicolumn{3}{|c|}{ - Villages } \\
\hline & Road & rainfed crop \\
\hline & Dunes & gossy steppe \\
\hline 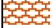 & Bare rock & $\therefore \quad$ Shrub steppe \\
\hline & Ponds & 离称 \\
\hline & intermittent flow (Kori) & riparian area \\
\hline & fallow & \\
\hline
\end{tabular}

Kilometers

Figure 4. Keita land use map in 1995. 


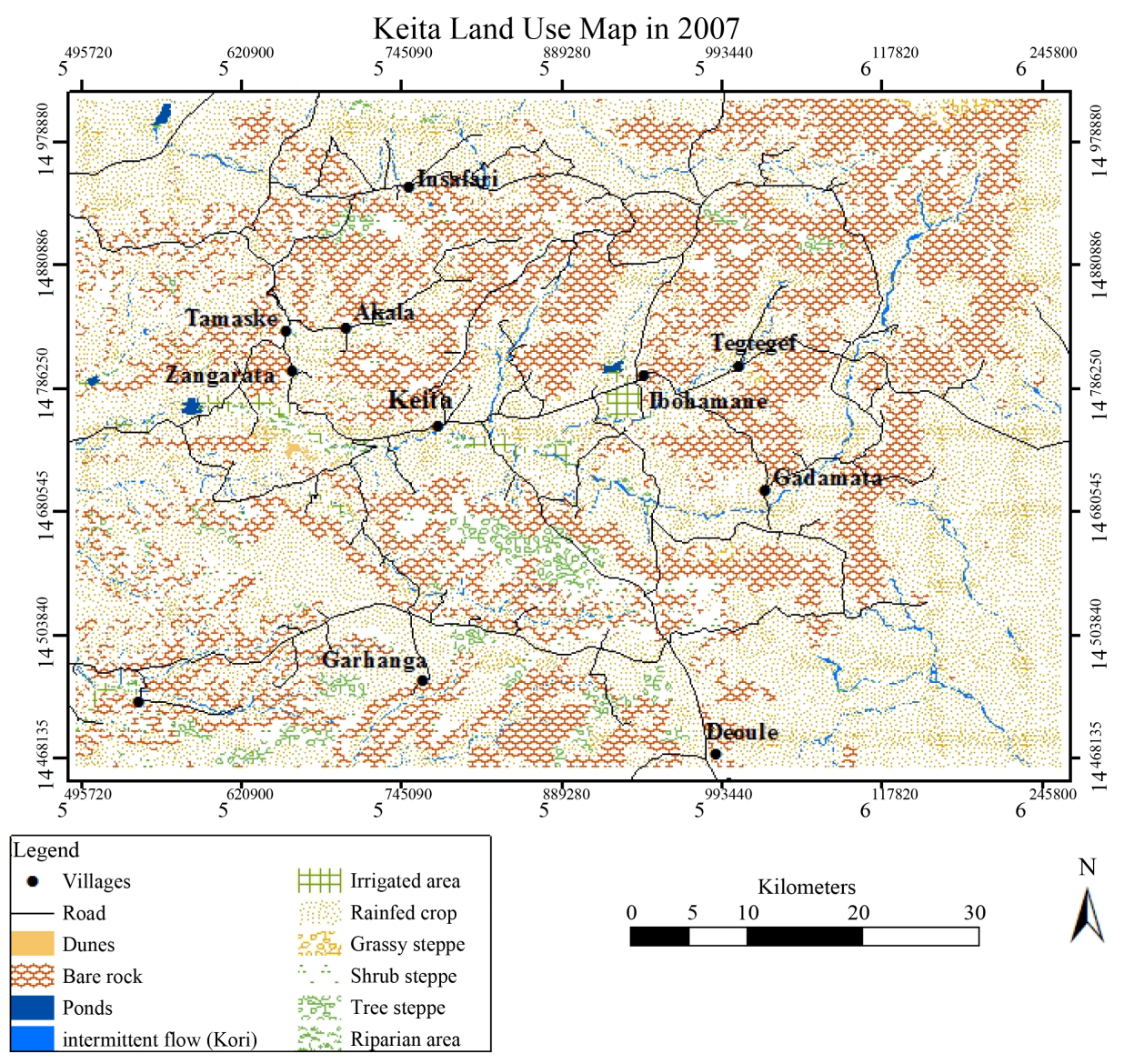

Figure 5. Keita land use map in 2007.

pronounced (compared to the total exodus); this fact makes the phenomenon more serious, since the region is found in a manpower deficiency. However, one of the factors that had an impact on the population of Keita was the return of an unspecified number of members of different communities expelled from Nigeria in 1983. This reflects either a breakdown or the radical change in demographic composition of keita population leading to heavy pressure on limited resources. Thus, Tukey multiple mean proves that the most significance of the change is induced by human and their activities (Table 1).

Within the framework of land securization, Niger has embarked on the implementation of Ordinance 92-030 of 8 juillet1992 "with guiding principles for rural development policy of Niger". The principles are of two types: integrated management of natural resources and organization of rural areas; popular participation and changes in the role of the state. The central issue that arises is the clear distinction established by the law between the legal regime of agricultural land and the grazing area. Indeed, agricultural land is subject to ownership while on grazing land herders have a right of use and the land status is common. The right of use is defined by the decree 97-007 as "an occupying power, enjoyment and management acknowledged to pastors on their land." The text clearly states that "in any case the right of use does not constitute a right of ownership" withdraw any ambiguity at this level (Article 4) [19] (Adam, 2006). Thus the land reclaimed by the project for breeding, once common, are likely to be colonized by agriculture if appropriate management mechanisms were not took. It was the traditional land management that collapses under the pressure of the market economy and the monetization of natural resources. The lands that were common became land to colonize or to buy, exacerbating conflicts between farmers and herders, and between former operators and dealers.

\section{Conclusions}

The use of satellite imageries has shown the value of remote sensing tools and the importance of GIS in analyz- 
ing land use dynamics as it has affected the Keita environment. Qualitative observations of the land in order to generate land dynamic situation map. A long period time of 32 years was analyzed (1975-2007), population growth was the most significant leading to agricultural land increased, much more than any units (2\% - 59\%). The vegetation cover suffers from that change, it reveals a decrease in grassy land unit, thus the dynamics is marked by the growing decline in grazing areas, woodland and shrubs. With rocky landscape (30\%) the study area has undergone shifts to cropland while the potential arable land area is low. More so, due to increasing population, fallow is becoming a thing of the past.

Land use/cover change in Keita supports the conclusion that the simple answers found in population growth, socio economic, land policy provide an adequate understanding of land change. Rather, individual and social responses follow from changing economic conditions, mediated by institutional factors. Opportunities and constraints for new land uses are created by markets and policies, increasingly influenced by global factors. Extreme biophysical events occasionally trigger further changes. Various human-environment conditions react to and reshape the impacts of drivers differently, leading to specific pathways of land-use change (Lambin et al., 2001).

\section{Acknowledgements}

We acknowledge the (Projet PAFAGE, Ministère de l'Environnement/République du Niger-CeSIA-IBIMET/ CNR-Coopération Italienne) for the data they provided us. We are also thankful to Pr. Yamba Boubacar and Pr. Zhanqi Wang who made a great deal of professional help. We express our thanks to Badamassi Aboubacar.

\section{References}

[1] FAO (2015) Global Forest Resources Assessment, How Are the World’s Forests Changing? FAO, Rome, p. 56. www.fao.org/publications

[2] African Union, African Development Bank, Economic Commission for Africa (2010) Land Policy in Africa: A Framework to Strengthen Land Rights, Enhance Productivity and Secure Livelihoods. p. 60.

[3] Tsegaye, D., Moe, S.R., Vedeld, P. and Aynekulu, E. (2010) Land-Use/Cover Dynamics in Northern Afar Rangelands, Ethiopia. Agriculture, Ecosystems \& Environment, 139, 174-180. http://dx.doi.org/10.1016/j.agee.2010.07.017

[4] http://www.comap.ca/kmland/kmland/content/VRCPR/LADA/TR01-FCAM_E.htm

[5] Ouallet, A. (2013) Parcours, HDR, vol. 1, août 2012-Encadrements et mobilisations dans les villes africaines du patrimoine: l'exemple du religieux, HDR, vol. 2, août 2012-Recueil de publications, HDR, vol. 3, août 2012. Doctoral Dissertation, Aix-Marseille Université, Aix-en-Provence.

[6] Batterbury, S. and Warren, A. (2001) The African Sahel 25 Years after the Great Drought: Assessing Progress and Moving towards new Agendas and Approaches. Global Environmental Change, 11, 1-8. http://dx.doi.org/10.1016/S0959-3780(00)00040-6

[7] Reenberg, A. (2001) Agricultural Land Use Pattern Dynamics in the Sudan-Sahel-Towards an Event-Driven Framework. Land Use Policy, 18, 309-319. http://dx.doi.org/10.1016/S0264-8377(01)00020-5

[8] PAFAGE (2005) Suivi de la repopulation végétale et de la biodiversité floristique. Système d’Information sur l'Environnement de Keita (SIE-KEITA), 71 p.

[9] PEICRE (1998) Projet D’evaluation des Interventions Pour La Conservation et La Recuperation de L'environnement. Note de Synthèse, p. 32.

[10] Tarchiani, V. and Roua, B. (2010) La problématique foncière et la gestion pastorale entre décentralisation et développement local: le cas de Keita au Niger. Science et changements planétaires/Sécheresse, 21, 203-210.

[11] National Institute of Statistics (2012) National Census (RGP/H).

[12] Reenberg, A. and Paarup-Laursen, B. (1997) Determinants for Land Use Strategies in a Sahelian Agro-EcosystemAnthropological and Ecological Geographical Aspects of Natural Resource Management. Agricultural Systems, 53, 209-229. http://dx.doi.org/10.1016/S0308-521X(96)00062-5

[13] Larwanou, M. and Saadou, M. (2011) The Role of Human Interventions in Tree Dynamics and Environmental Rehabilitation in the Sahel Zone of Niger. Journal of Arid Environments, 75, 194-200. http://dx.doi.org/10.1016/j.jaridenv.2010.09.016

[14] Haji, S. (1994) Desertification in Africa, Evidence from a Study in Niger. p. 112.

[15] Herrmann, S.M., Anyamba, A. and Tucker, C.J. (2005) Recent Trends in Vegetation Dynamics in the African Sahel and Their Relationship to Climate. Global Environmental Change, 15, 394-404. http://dx.doi.org/10.1016/j.gloenvcha.2005.08.004 
[16] Lambin, E.F., Turner, B.L., Geist, H.J., Agbola, S.B., Angelsen, A., Bruce, J.W., et al. (2001) The Causes of Land-Use and Land-Cover Change: Moving beyond the Myths. Global Environmental Change, 11, 261-269. http://dx.doi.org/10.1016/S0959-3780(01)00007-3

[17] ROSELT (2006) Caractérisation des sols et évaluation des ressources édaphiques; observatoire de Tahoua et Tillabéry Nord pour le Suivi Ecologique a long terme. Coordination Nationale du Niger, Report, 22 p.

[18] Issiaka I.M., Yamba, B. and Gu, Y. (2012) Land-Use and Land-Cover Change in Semi-Arid Zone: The Case of WaroSouloulou Area in Goulbi Maradi Watershed in the Republic of Niger. Environment and Natural Resources Research, 2, 1.

[19] Adam, M.K. (2006) Conference Internationale sur La Reforme Agraire et Le Developpement Rural (CIRADR). Etude de cas du Niger, Document pour l'atelier de dialogue thématique, Bresil, p. 28. 